\title{
PEDAGOGICAL STRATEGIES THAT IMPROVE CHILDREN'S PLAY-BASED LEARNING
}

\author{
Ona Monkevičienė \\ Kristina Stankevičienè \\ Birutė Autukevičienė \\ Marija Jonilienè \\ Lithuanian University of Educational Sciences
}

\begin{abstract}
This article focuses on the analysis of the issue of children and play-based learning. The theoretical position that play and learning are frequently integrated processes for a child and that there are methods of teacher-child interaction which make play-based learning more efficient, is followed. The pedagogical strategies that enable a child to learn through play without disrupting the authenticity of the play itself are theoretically substantiated: the strategy for promotion of children's learning "en passant", the strategy for initiation and promotion of joint attention, the strategy for promotion of children's learning from peers, the strategy for promotion of communicative teacher-children encounters in play and the strategy for promotion of children's reflection on play-based learning. On the basis of the qualitative research, the specific methods of practical implementation of each strategy have been described.
\end{abstract}

Keywords: early childhood, learning, pedagogical strategies, play.

\section{Introduction}

The scientific substantiation of children's play-based learning is an urgent problem. Though play is the activity that meets children's educational needs best, educational institutions frequently concentrate on learning rather than on play (Pramling Samuelson \& Asplund Carlsson, 2008). This situation is predetermined by the peculiarities of the organisation of education in general. The early childhood education curricula provide for certain learning outcomes. Seeking a targeted attainment of the outcomes, teachers initiate activities aimed at children's direct learning. Play cannot be directly used in the pursuance of learning outcomes by teachers because it is initiated and developed by children themselves. Therefore, less time is allocated to play. In this case, play and learning are viewed as two separate activities.

Research studies have intensively focused on another conceptual framework, where play and learning are seen as an intertwined totality (Brock, Dodds, 
Jarvis, \& Olusoga, 2009; Sommer, Pramling Samuelson, \& Hundeide, 2010; Cutter-Mackenzie \& Edwards, 2013). The studies of recent years have emphasised that play and learning are not always separate activities when approached from the child's perspective. The concept of "the playing learning child" is highlighted (Pramling Samuelson \& Asplund Carlsson, 2008, p. 624). The researchers also emphasise the shift from children's learning to their development in instructions (Eun, 2010; Hatch, 2010; Fumoto, 2011; Yelland, 2011).

The formulation of the aforementioned approach raises the issue of pedagogical strategies. Cheng and Stimpson (2004) outline that the involvement of an adult in children's play is not clearly understood or practised. Their research revealed a conflict between the theory of play-based learning as understood by teachers and the reality of play. A number of teachers use play only for raising children's interest and then proceed to direct teaching. Other teachers focus either only on free play or on direct learning. A positive investigative attitude of teachers towards children's play-based learning is necessary, where teachers search for appropriate pedagogical strategies. Conducting research into the teacher's role in 4 and 5 year old children's consumption of media via computers, mobile phones, etc. and the playing of computer games, Vangsnes and Økland (2013) identified the phenomenon of didactic dissonance. The authors perceive didactic dissonance as situations where a teacher and a child assume different conflicting roles and have different expectations, which impedes the process of children's learning. Teachers also encounter a similar didactic dissonance searching for their own didactic role in children's role-play. Involved in role-play, a child plays an assumed role of a performer as well as an observer and creator of a play situation. The didactic role of the teacher in children's role-play should be the creation of didactic interpersonal interaction with a child on the basis of the play situation. At present, teachers either avoid interfering in children's play, i.e. they do not establish didactic interpersonal relationships and learning situations, or they make attempts to supervise children's play, i.e. they deprive children of the joy of play development and turn play into an official process of learning. Few teachers assume the role of an assistant to a playing child, which does not contradict the position of children as players and observers of their own play. Through interpersonal interaction with children, such a teacher facilitates creation of learning situations for children, which naturally merge with the play developed by children themselves.

According to Pramling Samuelson and Asplund Carlsson (2008) the concept of the objective should be at the centre of pedagogical strategies. A playing learning child is concentrated on something, on an objective, whereas during the process of learning the emphasis is laid only on what has to be learnt. Because of this, the pedagogical strategies for promotion of children's play-based learning 
and the strategies for initiation and maintenance of learning are different. Direct orientation of a child during his/her play towards learning outcomes planned in advance may ruin the very play of a child. Teachers have to apply techniques which contribute to retaining the child's authentic play (freedom to choose what and how to play, a free flow of thoughts and imagination), and simultaneously draw attention to the object of learning. Teachers are not supposed to choose the object of learning in advance. It should arise from the child's play and should be given central attention by the child and the teacher for significant time. This article presents the research on what pedagogical strategies and techniques may improve children's play-based learning without destroying children's authentic play.

The goal of this research is to reveal methods of practical implementation of pedagogical strategies that enable children's play-based learning, which do not disrupt children's authentic play. The data were collected and analysed applying the qualitative research approach and the strategy of grounded theory (Corbin \& Strauss 2008).

\section{Theoretical framework}

The theories of constructivism and social constructivism are significant for theoretical modelling of strategies for promotion of children's play-based learning. Children's play-based learning is explained by the concept of learning "en passant" (Reischmann, 1986; Hille, Evanschitzsky, \& Bauer, 2013). Reischmann (1986, p. 2) argues that the following features are characteristic of such learning: "a) short learning situations, b) situations where less than half of the person's total motivation is on learning, c) contents hat are not "clear in the sense that the learner knows in advance what and how to use it or whether it will produce some lasting changes in himself". Hille et al. (2013) adapt these ideas to activities and play of early age children stating that while learning "en passant", efforts of children are directed not towards what he or she wants to learn but towards a different goal, i.e. to playing his/her favourite game, to experience something memorable or to communicate with others. Pursuing other goals, a child learns many useful things. Such learning may also be referred to as unintentional, informal, or non-formal, but according to some researchers, the prefixes $u n$, in, and non, create a negative connotation, whereas this way of learning is essentially positive and highly efficient. Seeking to empower a child for learning, a teacher should apply pedagogical strategies for promotion of learning "en passant". The main scheme of their application is presented in Figure 1a (p. 6).

Much of children's play is based on social interaction. Therefore, while playing, children learn from each other; they gain interest, observe, model their play and help each other (Eggum-Wilkens, Fabes, Castle, Zhang, Hanish, \& 
Martintc, 2014; Tatsis, Kafoussi, \& Skoumpourdi, 2008). Children tend to investigate "each other's conflicting ideas", "ways of thinking"; they negotiate, discuss and provide arguments to accept or reject concepts, which are mentioned by their peers (Pramling Samuelson \& Asplund Carlsson, 2008, p. 627). In the social context of learning, the theory is grounded on the ideas of Vygotsky's social constructivism and highlights the synergetic effect of learning together, the establishment of a common educational field and the construction of common knowledge (Vygotsky, 1981, 1987, 1997, as cited in Smidt, 2009). It is important for teachers to apply the strategy for the promotion of children's learning from peers. The scheme of its application is provided in Figure 1c (p. 6).

Pedagogical strategies, which are used to promote children's play-based learning without destroying the authenticity of child's play are grounded on the theory of joint attention. According to Pramling and Pramling Samuelsson (2011), early childhood didactics is the interaction and communication between a teacher and a child, when they achieve intersubjectivity and joint attention or sustained shared thinking. Joint activities, and communication in particular, serve as a basis for natural interaction during children's play. This is significant for a teacher in order to identify and sense what a child focuses on while playing, to demonstrate that a teacher is interested in the same things as a child is (to take a look either at the object from the point of view of a child, to use pointing gestures, to comment or ask), to encourage a child to constantly shift his/her attention from the object to the teacher, to feel an emotional connection with a child and to coordinate the process of maintaining attention with him/her, and to respond to the child's initiated wish to establish joint attention with the teacher (Barton \& Tomasello, 1991; Hobson, 2007; Racine \& Carpendale, 2007). When a child is young (1-3 years), the situation of joint attention embraces the concept of the initiator of attention, the one who responds and simultaneously coordinates glances, gestures and speaks, as well as a real object of interest. When a child is older (4-6 years), the object of interest may be symbolic (speaking about something, involving in fantasies, thinking together, etc.). Sewell, St George and Cullen (2013) conducted research focussing on both joint participation of teachers and children in play, and only on that of children. Joint participation is a reciprocal activity of a dialogic and responsive nature and it is based on joint attention. Initiating and maintaining joint attention with a playing child, a teacher may enhance the child's learning. However, it is also highly important to notice a child's interest and to allow him/her to develop authentic play joining the flow of a child's thoughts, supporting and expanding them, encouraging a child to create personal meanings and common knowledge rather than directing a child's play in a new direction. The scheme of the pedagogical strategy for initiation and maintenance of joint attention is presented in Figure $1 b$ (p. 6). 
The theory of communicative-didactic encounters between a teacher and a child (Pramling \& Pramling Samuelsson, 2011), based on ideas of two-way interaction between a teacher and a child, concentrates on a child's empowerment, scaffolding (Zurek, Torquati, \& Acar, 2013), co-constructing of knowledge, thinking, joint problem solving, educational dialogue (Skidmore, 2007; Littelon \& Howe, 2010), listening and responding to children's talk, questioning, modelling, and challenging and encouragement (Yelland, 2011). Applying these methods in encouraging children's play-based learning, a teacher should approach play from the child's perspective, i.e. to interpret children's play and learning as two interconnected processes. The interaction between a teacher and a child during play should comply with the nature of a child's play; a teacher has to be involved in the play just like a child and has to create genuine learning situations that naturally merge with play. The set educational goals also have to comply with the nature of play; a teacher should aim to encourage a playing child to learn about the surrounding world and to create meanings and should do it by supporting the child's ideas, drawing his/her attention to the objects that are relevant to exploration, creating challenging situations for a playing child and applying other methods that do not destroy the authenticity of the play (Pramling Samuelson \& Asplund Carlsson, 2008). The scheme of the strategy for promotion of communicative teacher-children encounters in play is provided in Figure 1d (p. 6).

Meta-cognitive and meta-communicative theories are useful for the development of strategies for promotion of children's play-based learning. They also substantiate the benefit of reflection on the experiences and learning techniques obtained during play. The research conducted by Robson (2010, p. 228) shows that child's meta-cognition consists of three components of metacognitive knowledge: the first one embraces perception of the self and others as learners as well as understanding the learning processes, the second one includes distinction of intentions or goals and "recognition that different tasks make different types of cognitive demand", the third element refers to awareness of "strategies to be used to solve identified problems and to meet goals". Lee, Teo and Bergin (2009) distinguish the following subcomponents of children's metacognition: procedural knowledge, declarative knowledge and conditional knowledge. Besides meta-cognitive knowledge, the authors also single out metacognitive regulation, whereas Robson (2010, p. 232) sees "emotional and motivational regulation" as particularly significant. In Robson's opinion, manifestations of children's meta-cognition may be naturally observed in their play, and its development has a considerable influence on children's selfregulated learning. Self-reflection and reflective dialogues are of significance to children's meta-cognitive knowledge and regulation (Bernard, Proust, \& Clément, 2015; Robson, 2010). Children's reflection on play-based learning may be conducted in different ways: "verbally, in drawings, in play, in experiments". 
It helps "to make the invisible visible for children" (Pramling Samuelson \& Asplund Carlsson, 2008, p. 635). Thus, seeking to encourage children's playbased learning, teachers may successfully apply strategies for promotion of children's reflections on learning experiences and techniques. Application of the aforesaid strategies does not disrupt children's authentic play because experiences are reflected upon when play is over. Reflection is particularly useful to the future play of children, i.e. it is oriented towards the future. The scheme of strategy for promotion of children's reflection on play-based learning experiences and techniques is presented in Figure 1e (p. 6).

The aforementioned pedagogical strategies are implemented by early childhood teachers and applied in various ways. The strategies were singled out and described in the organised qualitative research.

The research is based on the synthesis of the theories of Piaget's cognitive constructivism and Vygotsky's social constructivism (Piaget, 1951, 1961, Vygotsky, 1978, as cited in Pollard, Anderson, Maddock, Swaffield, Warin, \& Warwick, 2008), which predetermines the choice of a methodological approach. According to the above-mentioned theories, a child constructs his own worldperception and ways of learning about his surroundings with the help of social interactions. From the ontological perspective the reality of education is interpreted as relative, holistic and dynamic, whereas approaching education epistemologically, the reality is perceived as subjective, transactional and interactive (Arthur, Waring, Coe, \& Hedges, 2012). The data were collected and analysed applying the qualitative research approach and the strategy of grounded theory (Corbin \& Strauss, 2008). Such an approach allowed the researchers to reveal teachers' experiences (Cohen, Manion, \& Morrison, 2011), i.e. what methods they use applying different strategies for promotion of children's playbased learning, concepts of which are elaborated on in the theoretical framework of the article. Following Brown (1987), the activity strategy is understood as a totality of goal-oriented methods and ways of monitoring results of their application. The research aimed to disclose one aspect of pedagogical strategy application - to distinguish specific methods promoting children's play-based learning that are applied by teachers. 


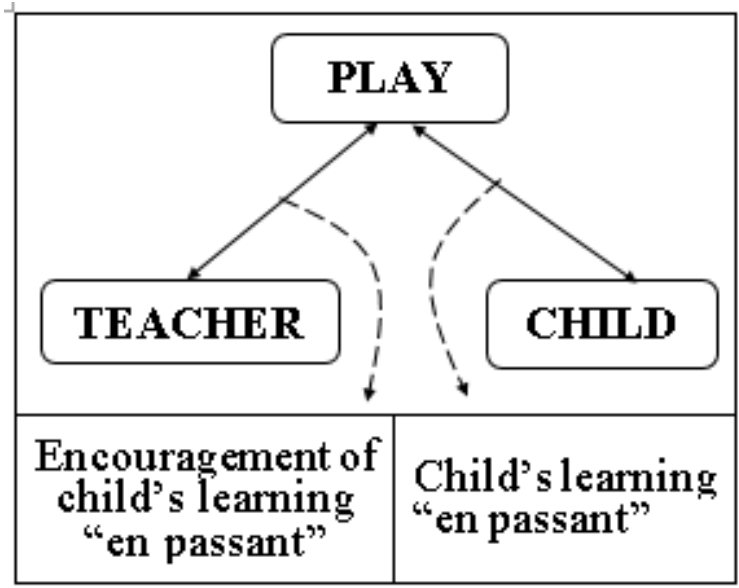

Figure 1a The strategy for promotion of child's learning "en passant"

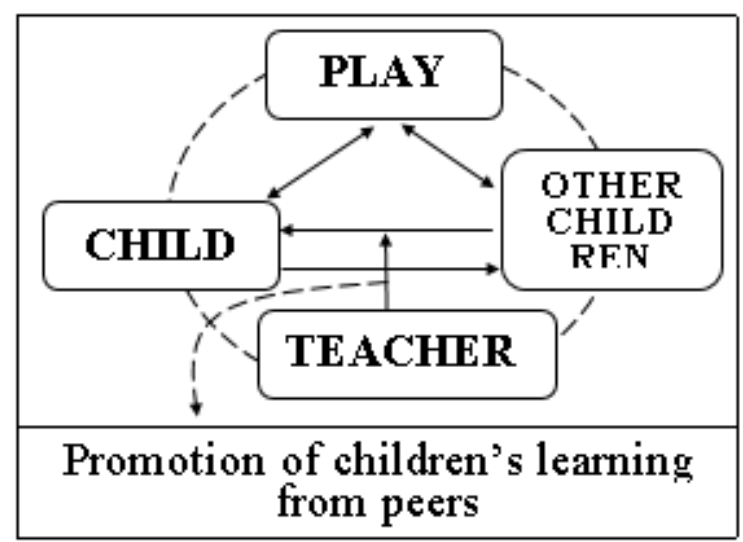

Figure 1c The strategy for promotion of children's learning from peers

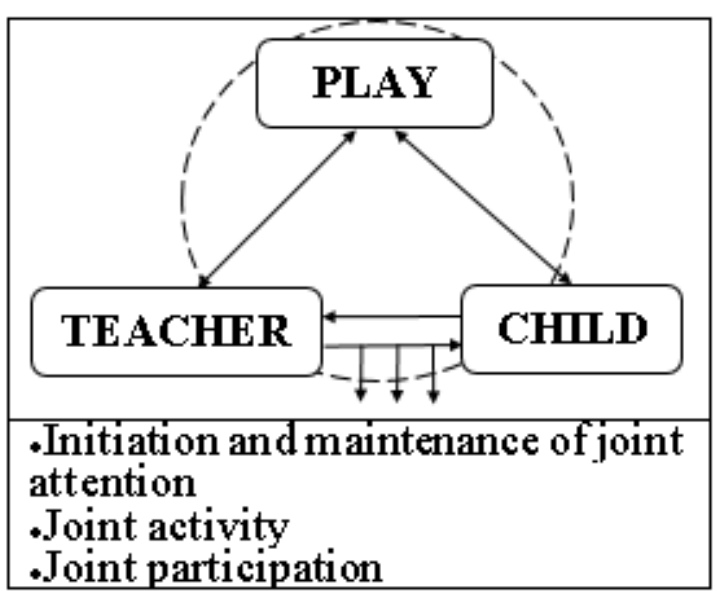

Figure $1 \mathrm{~b}$ The strategy for initiation and promotion of joint attention

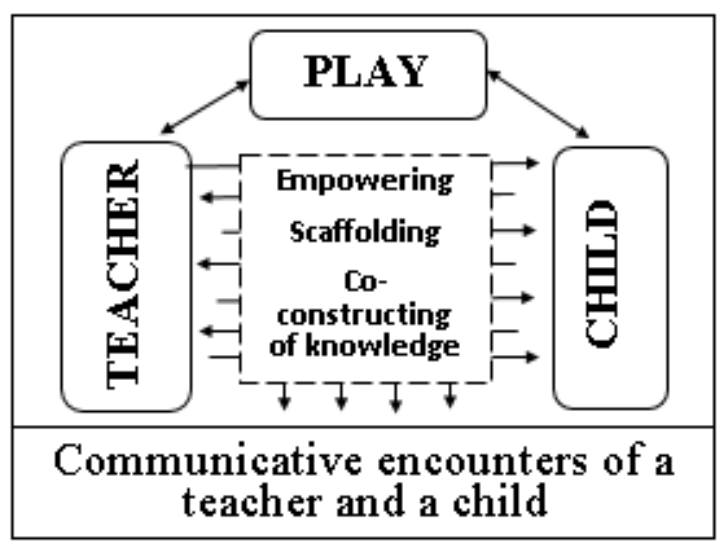

Figure 1d The strategy of communicative - didactic encounters of a teacher and a child in play

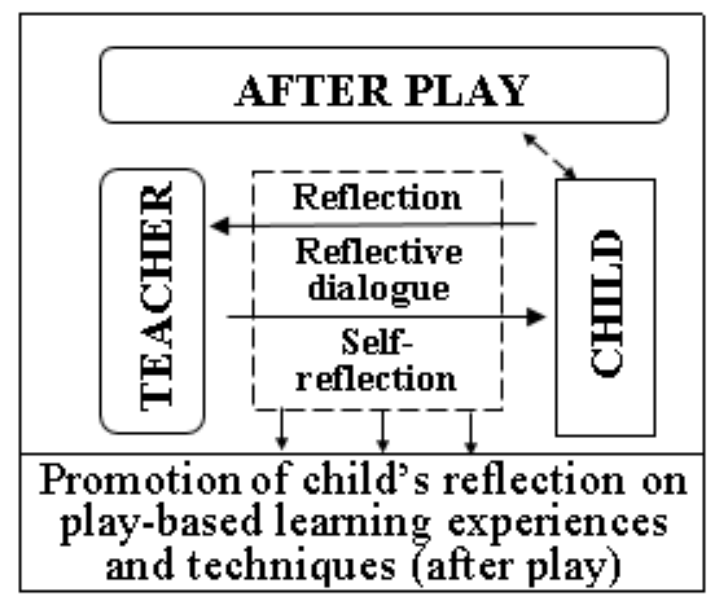

Figure 1e The strategy for promotion of child's reflection on play-based learning

Figure 1 Pedagogical strategies for promotion of child's play-based learning 


\section{Methodology}

Participants. The practical application of pedagogical strategies that enable children to learn through play and do not interfere with children's play is a subtle pedagogical problem. The depth of the research can be ensured only by working with professional teachers, who are able to reflect upon educational practice. Therefore, a number of requirements for participants were set by the researchers. The participants in the research were teachers with at least five years of practical experience, who organise the process of education from the child's perspective and are holders of a Master's degree. The method of theoretical sampling was applied (Corbin \& Strauss, 2008, pp. 143-145), where the research is conducted until it reaches the point of saturation. The sample consisted of 17 teachers.

Measurement instruments. The strategy of grounded theory is appropriate for research analysing interactions between individuals. The researchers used individual semi-structured interviews with the teachers to collect the data. The participants were provided questions regarding application practices of five strategies that enable children's play-based learning in their groups. The interviews were recorded and transcribed later.

The data were analysed in several stages (Corbin \& Strauss, 2008, pp. 159160). The three phases of coding (open, axial and selective) were utilised to interpret the transcribed interviews. During the first stage one of the researchers carried out open coding of the material of the first interviews with the teachers. Then the other three researchers looked through and together reflected upon all the possible meanings of open coding concepts. During the axial coding phase, the codes were reanalysed and combined into broader themes. All four researchers conducted the analysis at this stage. Having completed this stage the research field was revisited and the procedure was repeated. During the stage of selective coding the researchers distinguished the concepts of highest level, i.e. the best methods of interfering with play to enable children's play-based learning.

The triangulation of data source, methods and researchers was ensured (Miles, Huberman, \& Saldana, 2014, p. 299).

\section{Findings}

The results of the data analysis are presented separately, showing practices of application of five pedagogical strategies. The tables firstly indicate a specific method of the teacher's interference with play or its stimulation to promote playbased learning, and then one or several extracts from the interview with the teachers are presented.

Methods of practical application of the strategy for promotion of children's learning "en passant" (unintentional, informal learning). The observed practices of teachers reveal that establishment of a rich learning 
environment that engages with play, its constant renewal as well as sufficient time for starting and developing play may be considered the most important aspects of promotion of children's learning "en passant". Several cases in practice were observed where teachers themselves initiated children's play or facilitated involvement of a certain child into play. Only one specific method to encourage children's learning "en passant", was identified and it involved communication with children during their preparation for play (Table 1). All the teachers who took part in the research emphasised that play is the main activity that contributes to children's development.

Enrichment, change and conversion of environment evoke new ideas for play. When play occurs under different conditions, new problems and opportunities are opened up and, thus, children's learning "en passant" is stimulated. The teachers emphasised that children learn naturally while playing, they do not set goals to learn something and their intentions are "to play the game they have thought of", "to play with their own toy", "to communicate with a friend", "to do something with others", and "to manage others". However, a number of children's intentions can be linked to learning: "to experience interesting things", "to try out new activities in play", "to demonstrate in play what has been read to them", "to apply what has been learnt during other activities in play". On the other hand, the aforementioned reaction of teachers during the interviews shows that they do not observe features of children's learning "en passant", emphasising that it occurs spontaneously. This is why they do not specifically search for ways to stimulate children's learning "en passant".

Table 1 Methods to promote children's learning "en passant"

\begin{tabular}{|l|l|}
\hline \multicolumn{1}{|c|}{ Methods } & \multicolumn{1}{c|}{ Interview with teachers } \\
\hline $\begin{array}{l}\text { Establishment of } \\
\text { environment that } \\
\text { engages play, its } \\
\text { constant renewal, setting } \\
\text { of time. }\end{array}$ & $\begin{array}{l}\text { "I notice what children are interested in and create an appropriate } \\
\text { educational environment", T1; "I make attempts to supplement } \\
\text { groups with new aids", "I strive to motivate children to play with } \\
\text { new toys or toys that are interesting in one or another way", "My } \\
\text { children know that they are allowed to play at any time of the day". }\end{array}$ \\
\hline $\begin{array}{l}\text { Change of location and } \\
\text { time of play to activate } \\
\text { it. }\end{array}$ & $\begin{array}{l}\text { "When children's play falls into routine, we rearrange the group } \\
\text { together with children and come up with new ideas for play", } \\
\text { "Friday is a day, when children bring toys from home and this } \\
\text { increases the variety in their play". }\end{array}$ \\
\hline $\begin{array}{l}\text { Communication with } \\
\text { children during their } \\
\text { preparation for play. }\end{array}$ & $\begin{array}{l}\text { "While children get ready for play, we talk, consult with children } \\
\text { or rejoice at something". }\end{array}$ \\
\hline Initiation of play. & $\begin{array}{l}\text { "Sometimes I start an unexpected game with children and then } \\
\text { leave them to further develop it", "I start playing with a child, } \\
\text { who is not accepted by other children, and when others join us, I } \\
\text { leave them to further play together". }\end{array}$ \\
\hline
\end{tabular}


Methods of practical application of the strategy for promotion of children's learning from peers. Children learning from each other is grounded on a variety of interactions, which creates a field of opportunities, as well as being based on the depth of the interactions. The data provided in Table 2 show that the teachers tend to more frequently focus on such methods that promote children's learning from peers, which increase the variety of opportunities for interaction. They encourage children to change play partners, regroup, address another child for information or help and to offer information or help to others, and share information received from the teacher with other children. A few methods applied by teachers to promote the depth of children's interactions were singled out: creation of situations where children solve emerging problems together, and encouragement of children's dialogues and discussions.

A limited application of methods that enhance children's learning from their peers may be observed because of insufficient teacher understanding. The teachers notice only less complex ways of children's peer learning: observation and modelling, provision of advice, explanation, exchange of possessed information, and support and collaboration. Failing to notice more complex processes of peer learning, the teachers are not able to search for and test methods of pedagogical effect that stimulate the aforesaid processes.

On the other hand, the methods to stimulate children's learning from peers that are applied by the teachers are non-academic, sufficiently efficient and, above all, do not disrupt the authenticity of children's play.

\section{Table 2 Methods to promote children's learning from peers}

\begin{tabular}{|l|l|}
\hline \multicolumn{1}{|c|}{ Methods } & \multicolumn{1}{c|}{ Interview with teachers } \\
\hline $\begin{array}{l}\text { Encouragement of children's } \\
\text { play in pairs or groups to } \\
\text { create opportunities to } \\
\text { observe each other, and to } \\
\text { cooperate and learn from } \\
\text { each other. }\end{array}$ & $\begin{array}{l}\text { "Children's abilities, interests and experience are different. } \\
\text { Therefore, I encourage them to play not only in the same } \\
\text { pair or group but also with other children. Thus, children } \\
\text { get more opportunities to learn from others." }\end{array}$ \\
\hline $\begin{array}{l}\text { Creation of situations where } \\
\text { children have to share } \\
\text { information, solve problems } \\
\text { together, and learn from } \\
\text { each other. }\end{array}$ & $\begin{array}{l}\text { "If playing school or hairdresser's parlour the same child } \\
\text { takes the role of a teacher or a hairdresser, it is possible to } \\
\text { suggest one or another role to a different child and children } \\
\text { will "learn" from each other different things." }\end{array}$ \\
\hline $\begin{array}{l}\text { Proposal to address another } \\
\text { child for information or } \\
\text { help; to share information } \\
\text { with another child or to help } \\
\text { him/her. }\end{array}$ & $\begin{array}{l}\text { "When children play together and one of them does not } \\
\text { know something and I know that another child knows this, } \\
\text { I always say: "Go to him or her and ask", "I frequently } \\
\text { encourage children to come with new ideas about play } \\
\text { from home and to develop new plots with others", "when I } \\
\text { notice that one child helps another, I always praise them". }\end{array}$ \\
\hline
\end{tabular}




\begin{tabular}{|l|l|}
\hline $\begin{array}{l}\text { Encouragement of children's } \\
\text { dialogues and discussions } \\
\text { among themselves. }\end{array}$ & $\begin{array}{l}\text { "I start a dialogue with a playing child and encourage } \\
\text { his/her dialogue with other children to exchange their } \\
\text { different ideas", "I bring the difference in opinions to their } \\
\text { attention". }\end{array}$ \\
\hline $\begin{array}{l}\text { Teaching of several children } \\
\text { through play to enable them } \\
\text { to teach other children. }\end{array}$ & $\begin{array}{l}\text { "Firstly I show to the children, who are more interested at } \\
\text { that moment and they teach others". }\end{array}$ \\
\hline
\end{tabular}

Methods of practical application of the strategy for initiation and maintenance of joint attention. The situations of joint attention or joint participation facilitate establishment of a teacher's close personal relationship with a child and have a deep educational value. The research highlighted a whole range of ways to initiate and maintain joint attention which may be grouped into physical proximity and maintenance of eye contact; conversation about the object of children's interest; asking questions that are based on children's experience, stimulating his/her thinking or activity; performing activities together with a child, maintenance of emotional connection (Table 3).

Table 3 Methods to initiate and maintain joint attention of a playing child

\begin{tabular}{|l|l|}
\hline \multicolumn{1}{|c|}{ Methods } & \multicolumn{1}{|c|}{ Interview with teachers } \\
\hline Physically approaching a child & $\begin{array}{l}\text { "I come up to a child, sit down next to him/her", } \\
\text { "we sit down together on the carpet". }\end{array}$ \\
\hline $\begin{array}{l}\text { Shift of a glance from a child to an } \\
\text { object, catching of child's eye contact } \\
\text { and maintaining it. }\end{array}$ & $\begin{array}{l}\text { "When a child shows an object, I look at it and } \\
\text { show my interest", "if a child speaks about } \\
\text { something, I also talk about it with him/her". }\end{array}$ \\
\hline $\begin{array}{l}\text { Showing an object of interest to a } \\
\text { child (if the object is real) or its } \\
\text { emotional designation (if the object is } \\
\text { symbolic). }\end{array}$ & $\begin{array}{l}\text { "I show a more interesting object from the ones } \\
\text { that a child is interested in", "I show the details } \\
\text { that make difference or are somehow special", "I } \\
\text { name it expressively". }\end{array}$ \\
\hline $\begin{array}{l}\text { Speaking about the object of interest } \\
\text { to a child in play in an expressive } \\
\text { voice and body language. }\end{array}$ & $\begin{array}{l}\text { "I listen to what a child wants to say to me", "I } \\
\text { say something to a child if he/she needs it", "I } \\
\text { speak in an emotional way". }\end{array}$ \\
\hline $\begin{array}{l}\text { Asking questions that concentrate on } \\
\text { revelation and reflection of a child's } \\
\text { experience. }\end{array}$ & $\begin{array}{l}\text { "I ask targeted questions to enable a child to } \\
\text { remember what he/she knows or is able to do", "I } \\
\text { remind a child of what he/she has already done or } \\
\text { may apply in a new play situation". }\end{array}$ \\
\hline $\begin{array}{l}\text { Asking questions: presentation of } \\
\text { problem-based questions, questions } \\
\text { that evoke thinking, re-asking of } \\
\text { questions. }\end{array}$ & $\begin{array}{l}\text { "I ask the questions that children don't expect", } \\
\text { "when a child says "I don't know", I ask them } \\
\text { questions, which encourage a child to make } \\
\text { attempts to learn to do it". }\end{array}$ \\
\hline $\begin{array}{l}\text { Asking questions that facilitate } \\
\text { play and activities. }\end{array}$ & $\begin{array}{l}\text { "I ask something in such a way, which encourages } \\
\text { a child to play in an unusual or different way", } \\
\text { "when children speak about something, I suggest } \\
\text { them implementing it practically". }\end{array}$ \\
\hline
\end{tabular}




\begin{tabular}{|l|l|}
\hline $\begin{array}{l}\text { Using the object of interest to a child } \\
\text { in activities together with a child, } \\
\text { doing what a child proposes or asks. }\end{array}$ & $\begin{array}{l}\text { "I join the child's play", "a child tells me what to } \\
\text { do and I obey the instructions". }\end{array}$ \\
\hline $\begin{array}{l}\text { Involvement of a child in a situation } \\
\text { of joint attention through } \\
\text { demonstrative activities. }\end{array}$ & $\begin{array}{l}\text { "I play with what a child likes and the way a child } \\
\text { likes", "I create an interesting situation", "I } \\
\text { become a certain character". }\end{array}$ \\
\hline $\begin{array}{l}\text { Sincere interest in children's play, } \\
\text { maintenance of emotional relation } \\
\text { with a child. }\end{array}$ & $\begin{array}{l}\text { "When I smile, a child smiles back", "we laugh } \\
\text { together", "I make every attempt to wonder at } \\
\text { something". }\end{array}$ \\
\hline
\end{tabular}

The methods applied by the teachers are thoughtful, stimulate children's improvement, expand their world perception and enrich their learning strategies. Moreover, it is a two-way process, as a teacher also applies such methods as a response to joint attention situations initiated by a child.

The methods to initiate and maintain joint attention that are applied by the teacher are of particular value because the teacher follows the direction of a child's interest, the flow of his/her thoughts and, enriches his/her knowledge, and develops a child's broader thinking for new opportunities for activities and learning. Thus, a teacher's didactics merges with the direction of a child's authentic play and moments of impact are short and situation-based. Being aware of the educational outcomes to be pursued, a teacher finds an appropriate moment to get involved, when prerequisites for expansion of a child's knowledge or for development of a certain ability emerge.

The teachers demonstrated that they are able to recognise the features of a child's interest in something: "I notice what kind of play scenarios a child creates", "a child plays a certain game for a long time", "a child undertakes constructing in one place, then does the same in another", "he/she plays with an object", "asks adults and friends questions", "a child shows an object, explains something", "he/she asks to read about something or to tell something", "a child tells about something that is interesting to him", "he/she collects something", "I notice something following a child's emotions".

Methods to initiate and maintain joint attention are applied in the spirit of respect for authenticity of children's play.

Methods of practical application of the strategy for communicative didactic encounters of a teacher and a child in play. The communicative didactic encounters of a teacher and a child in play are different from the situations to initiate and maintain joint attention because the teacher expands and enriches the direction of a child's authentic play by the pedagogy of dialogue, which is more oriented towards creation of specific learning situations or acquisition of learning skills through play.

The methods applied by the teachers, when they apply the aforementioned strategy, (Table 4) are various and thoughtful because the majority of early 
childhood education strategies are appropriate for stimulation of play-based education: support acquiring necessary abilities, modelling, challenging, educational dialogue, co-construction of knowledge as well as ways to promote learning to learn (drawing attention to characteristic features of the problem; encouragement to foresee future; asking questions that stimulate drawing conclusions; linking with already possessed knowledge and experience) and confirming feedback. The teachers also indicated other methods which are less linked to creation of specific learning situations and development of learning abilities.

On the other hand, application of methods of promoting children's playbased learning has to be rather subtle to avoid the transition from child's play to learning, i.e. to prevent turning a child's goal to play into the goal to learn, to prevent turning a child's freedom to fantasise into following a course of thought connected to adult regulated activities.

Table 4 Methods of communicative didactic encounters of a teacher and a child in play

\begin{tabular}{|c|c|}
\hline Methods & Interview with teachers \\
\hline $\begin{array}{l}\text { Empowerment }- \text { support } \\
\text { acquiring necessary } \\
\text { abilities. }\end{array}$ & $\begin{array}{l}\text { "If it is necessary, I teach a child something what he/she } \\
\text { could use in play", "I teach children who lack certain play } \\
\text { skills playing together with them". }\end{array}$ \\
\hline Modelling & $\begin{array}{l}\text { "I make every attempt to use more complex verbal } \\
\text { constructions, to demonstrate models of behaviour", "I } \\
\text { encourage children to teach me". }\end{array}$ \\
\hline Challenging & $\begin{array}{l}\text { "Asking questions or using other ways I try to create new } \\
\text { and more complex situations for children to provide them } \\
\text { with challenges", "I direct them towards activities, which } \\
\text { can teach children something new". }\end{array}$ \\
\hline Educational dialogue & $\begin{array}{l}\text { "I conduct dialogues with children, which promote } \\
\text { information exchange, problem solution", "I maintain } \\
\text { dialogues of spontaneous exchange of thoughts". }\end{array}$ \\
\hline $\begin{array}{l}\text { Drawing attention to } \\
\text { features characteristic of the } \\
\text { problem. }\end{array}$ & $\begin{array}{l}\text { "When children encounter a certain problem and do not } \\
\text { know how to cope with it, I try to enable them to understand } \\
\text { why this is a problem". }\end{array}$ \\
\hline $\begin{array}{l}\text { Encouragement to foresee } \\
\text { future. }\end{array}$ & $\begin{array}{l}\text { "I teach children to think about the consequences and } \\
\text { future", "I encourage them to understand consequences of } \\
\text { their behaviour and actions". }\end{array}$ \\
\hline $\begin{array}{l}\text { Asking questions that } \\
\text { stimulate drawing } \\
\text { conclusions. }\end{array}$ & $\begin{array}{l}\text { "I encourage children to think about possible ways out", "I } \\
\text { aim at encouraging children to make conclusions } \\
\text { themselves". }\end{array}$ \\
\hline Confirming feedback. & $\begin{array}{l}\text { "I always notice, when a child succeeds and I praise him or } \\
\text { her", "I encourage not to give up and when a child succeeds, } \\
\text { I'm happy about it" }\end{array}$ \\
\hline
\end{tabular}


Methods of practical application of the strategy for promotion of child's reflection on play-based learning. Children's reflection on what was played and how, what was understood or learnt in play, how they learnt themselves, how they taught others, what difficulties were encountered and how they were addressed, help to draw their attention to learning situations in play, develop their metacognitive abilities and meta-cognitive regulation. Understanding that he/she learns all the time, how he/she learns and how a goal can be achieved, a child uses those abilities in their own play in a targeted way. Nevertheless, play retains its essence and self-regulating nature, and children's intentions to play and experience of pleasure do not undergo any changes.

Table 5 Methods to encourage children's reflection on play-based learning

\begin{tabular}{|l|l|}
\hline \multicolumn{1}{|c|}{ Methods } & \multicolumn{1}{|c|}{ Interview with teachers } \\
\hline $\begin{array}{l}\text { Observation of child's spontaneous } \\
\text { reflections and reactions to them. }\end{array}$ & $\begin{array}{l}\text { "Children constantly reflect what happened and } \\
\text { how, what their intentions were, how they } \\
\text { acted, whether they succeeded or not and why". }\end{array}$ \\
\hline $\begin{array}{l}\text { Encouragement of parents to ask their } \\
\text { children what they played and what } \\
\text { they learnt. }\end{array}$ & $\begin{array}{l}\text { "Children's parents tell me what children speak } \\
\text { about at home. I encourage them to ask what } \\
\text { and how they have learnt in play." }\end{array}$ \\
\hline $\begin{array}{l}\text { Encouragement of interest in reflections } \\
\text { of other children and learning from each } \\
\text { other how to do it. }\end{array}$ & $\begin{array}{l}\text { "I ask children to listen to what other children } \\
\text { speak. I also ask if they understand what their } \\
\text { friend has learnt." }\end{array}$ \\
\hline $\begin{array}{l}\text { Encouragement to verbally express the } \\
\text { acquired experience, to demonstrate by } \\
\text { actions, to reveal in drawings or } \\
\text { symbols. }\end{array}$ & $\begin{array}{l}\text { "I encourage children to draw what got stuck in } \\
\text { their heads", "I stimulate children's reflection } \\
\text { using traffic light colours", "using the images } \\
\text { of ears, eyes, hands and feet: what I have } \\
\text { heard, noticed or seen, done, etc." }\end{array}$ \\
\hline $\begin{array}{l}\text { Encouragement to remember events that } \\
\text { got stuck in their memory, their } \\
\text { sequence and play situations. }\end{array}$ & $\begin{array}{l}\text { "We reflect on what games we have played } \\
\text { over the day, how we have played and what has } \\
\text { happened". }\end{array}$ \\
\hline $\begin{array}{l}\text { Encouragement a child to express what } \\
\text { they learnt in play and how it happened, } \\
\text { what and how a child taught others and } \\
\text { what and how he/she learnt from others. }\end{array}$ & $\begin{array}{l}\text { "We discuss what we have learnt during the } \\
\text { day, what we have understood, whom we have } \\
\text { helped", "I ask what the girl and other children } \\
\text { have learnt". }\end{array}$ \\
\hline $\begin{array}{l}\text { Encouragement to speak about what } \\
\text { was successful, what difficulties were } \\
\text { encountered and how they were } \\
\text { eliminated. }\end{array}$ & $\begin{array}{l}\text { "We reflect at the end of the week: what we } \\
\text { have succeeded in, what we have failed and } \\
\text { why", "I asked in what way they tried to cope } \\
\text { with challenges and whether it was successful". }\end{array}$ \\
\hline
\end{tabular}

The research found that the teachers apply various methods to encourage children's reflection (Table 5), which embrace spontaneous reflections (communicating with friends, parents, teachers) as well as targeted reflections stimulated by adults (asking special questions); children are encouraged to express the acquired experience in various ways (verbally, acting, in drawing, 
symbols, etc.), the reflection is based on questions that enable children to understand the self and others as learners - how they and others are able to learn, how they do this; to perceive the strategies of goal attainment -what intention a child had, how he/she attained it and whether it was successful.

The teachers understand very well and emphasise the benefit of reflection to a child and for development of the basics of a child's abilities to learn.

\section{Discussion and conclusions}

Following the ideas of developmental pedagogy (Pramling Samuelsson and Pramling, 2013), dialogue pedagogy (Sheridan and Samuelsson, 2013), to play and learning centred pedagogy (Pramling Samuelson and Asplund Carlsson, 2008), five strategies for promotion of children's play-based learning have been modelled: the strategy for promotion of learning "en passant", the strategy for promotion of children's learning from peers, the strategy for initiation and maintenance of joint attention, the strategy of communicative-didactic teacherchild encounters in play, and the strategy for promotion of a child's reflection on play-based learning.

All five pedagogical strategies are based on interactive pedagogy and embrace child-teacher interactions before, during and after play. Learning is interpreted as formation of a child's new perspective rather than a narrow process of academic knowledge acquisition. It is considered that play, which provides opportunities to explore and discover, creates learning situations, whereas engagement of adults with children's play and interaction with them contributes to enhancement of children's play-based learning.

The encouragement of children's play-based learning relies on unintentional learning, when a child does not possess any preconceived intention to learn something but actually learns "en passant" or spontaneously through short intentional learning situations emerging in the general context of play without depriving a child of his/her intention to play. Such a theoretical position predetermines the position of teacher's engagement with play. The teacher is not inside the children's imaginary play. Such a teacher's position is highlighted by Fleer (2015), and is referred to as valuable in developing child's play rather than promoting child's play-based learning. The position of the teacher in the pedagogical situations modelled in the article is different. The teacher is outside of children's play when she applies the strategies for promotion of children's learning "en passant" or children's reflection on play-based learning. The teacher is following the children's play implementing the strategy for initiation and maintenance of joint attention. In such cases there is a difference in a child's intention and in that of the teacher. However, the child's intention is the dominating one: a child's intention is to play, he/she is fully engaged into the play 
developed by him/her. Meanwhile, the teacher's intention is to employ the child's interest in something and to expand his/her experience as well as finding ways of exploring the world and stimulating change in the child's perspective, i.e. to promote their learning through play. The teacher episodically engages with children's play and endeavours to create short situations of co-construction of knowledge applying the strategy of communicative-didactic encounters of a teacher and a child in play. In this case intentions are different as well. Moreover, they are in dialogue interaction: the child's intention is to play, whereas that of the teacher is to enhance or even to provoke short learning situations in the context of child's play. In some cases, the child's intentions naturally change from the intention to play to the intention to learn something and then again to the intention to play and, thus, short episodes, where the intentions of a child and a teacher coincide, may occur. When a teacher applies the strategy for promotion of peer learning among children, she may be outside of children's play, may follow it or be engaged with it.

All the modelled pedagogical strategies create prerequisites for improvement of children's play-based learning and do not disrupt authenticity of children's play if applied professionally. Practical implementation of the strategies for promotion of children's learning "en passant" and children's learning from peers has not been developed yet.

The goal and nature of the research did not allow for the modelling of situations of pedagogical effect and testing of their efficiency. Further research is needed whereby a methodological approach in cooperation with teachers could model and test the efficiency of pedagogical strategies. The results of the research suggest that a teacher's knowledge of play theory either encourages or limits application of certain pedagogical strategies. Scientific verification of the aforementioned statement is needed.

\section{References}

Arthur, J., Waring, M., Coe, R., \& Hedges, L. V. (2012). Research Methods and Methodologies in Education (3rd ed.). London: Sage.

Barton, M. E., \& Tomasello, M. (1991). Joint Attention and Conversation in Mother-InfantSibling Triads. Child Development, 62 (3), 517-529. doi.org/10.2307/1131127

Bernard, S., Proust, J., \& Clément, F. (2015). Procedural Metacognition and False Belief Understanding in 3 - to 5 - Year-Old Children. PloS ONE, 10 (10): e0141321. doi.org/10.1371/journal.pone.0141321

Brock, A., Dodds, S., Jarvis, P., \& Olusoga, Y. (2009). Perspectives on Play: Learning for Life. Harlow: Pearson Education.

Brown, A. (1987). Metacognition, Executive Control, Self-Regulation, and Other More Mysterious Mechanisms. In F. Weinert, \& R. Kluwe (Eds.), Metacognition, Motivation, and Understanding. Hillsdale: Erlbaum, 65-116. 
Cheng, D. P. W., \& Stimpson, P. (2004). Articulating Contrasts in Kindergarten Teachers' Implicit Knowledge on Play-Based Learning. International Journal of Educational Research, 41 (4/5), 339-352. doi.org/10.1016/j.ijer.2005.08.005

Cohen, L., Manion, L., \& Morrison, K. (2011). Research Methods in Education (7th ed.). Abingdon: Routledge.

Corbin, J., \& Strauss, A. (2008). Basics of Qualitative Research: Techniques and Procedures for Developing Grounded Theory (3rd ed.). Thousand Oaks: Sage Publications.

Cutter-Mackenzie, A., \& Edwards, S. (2013). Toward a Model for Early Childhood Environmental Education: Foregrounding, Developing, and Connecting Knowledge through Play-Based Learning. The Journal of Environmental Education, 44 (3), 195-213.

Eggum-Wilkens, N. D., Fabes, R. A., Castle, S., Zhang, L., Hanish, L. D., \& Martintc, C. L. (2014). Playing with Others: Head Start Children's Peer Play and Relations with Kindergarten School Competence. Early Childhood Research Quarterly, 29 (3), 345-356. doi.org/10.1016/j.ecresq.2014.04.008

Eun, B. (2010). From Learning to Development: a Sociocultural Approach to Instruction. Cambridge Journal of Education, 40 (4), 401-418. doi.org/10.1080/0305764X.2010.526593

Fleer, M. (2015). Pedagogical Positioning in Play - Teachers Being Inside and Outside of Children's Imaginary Play. Early Child Development and Care, 185 (11-12), 1801-1814. doi.org/10.1080/03004430.2015.1028393

Fumoto, H. (2011). Teacher-Child Relationship and Early Childhood Practice. Early Years, 31 (1), 19-30. doi.org/10.1080/09575146.2010.535790

Hatch, J. A. (2010). Rethinking the Relationship between Learning and Development: Teaching for Learning in Early Childhood Classrooms. The Educational Forum, 74 (3), 258-268. doi.org/10.1080/00131725.2010.483911

Hille, K., Evanschitzsky, P., \& Bauer, A. (2013). Das kind - die Entwicklung zwischen drei und sechs Jahreren. Köln: Bern.

Hobson, R. P. (2007). Hamlet without the Prince: Shortcomings of an Activity-Based Account of Joint Attention. British Journal of Developmental Psychology, 25, 27-32. doi.org/10.1348/026151006X156890

Lee, C. B., Teo, T., \& Bergin, D. (2009). Children's Use of Meta-Cognition in Solving Everyday Problems: An Initial Study from an Asian Context. Australian Educational Researcher, 36 (3), 89-102.

Littelon, K., \& Howe, C. (2010). Educational Dialogues Understanding and Promoting Productive Interaction. Abingdon: Routledge.

Miles, M. B., Huberman, A. M., \& Saldana, J. (2014). Qualitative Data Analysis. A Methods Sourcebook (3rd ed.). Thousand Oaks: Sage Publications.

Pollard, A., Anderson, J., Maddock, M., Swaffield, S., Warin, J., \& Warwick, P. (2008). Reflective Teaching: Evidence-Informed Professional Practice (3rd ed.). London: Continuum International Publishing Group.

Pramling Samuelsson, I., \& Asplund Carlsson, M. (2008). The Playing Learning Child. Towards a Pedagogy of Early Childhood. Scandinavian Journal of Educational Research, 52 (6), 623 - 641. doi.org/10.1080/00313830802497265

Pramling Samuelsson, I., \& Pramling, N. (2013). Orchestrating and Studying Children's and Teachers' Learning: Reflections on Developmental Research Approaches. Education Inquiry, 4 (3), 519-536. 
Pramling, N., \& Pramling Samuelsson, I. (Eds.). (2011). Educational Encounters: Nordic Studies in Early Childhood Didactics. Dordrecht: Springer. doi.org/10.1007/978-94-007$1617-9$

Racine, T. P., \& Carpendale, J. I. M. (2007). Shared Practices, Understanding, Language and Joint Attention. British Journal of Developmental Psychology, 25, 45-54.

Reischmann, J. (1986). Learning "en passant": The Forgotten Dimension. The paper presented at the Conference of the American Association of Adult and Continuing Education, Hollywood, Florida, October 23, 1986. Retrieved from http://www.reischmannfam.de/lit/1986-AAACE-Hollywood.pdf

Robson, S. (2010). Self-Regulation and Meta-Cognition in Young Children's Self-Initiated Play and Reflective Dialogue. International Journal of Early Years Education, 18 (3), 227-241.

Sewell, A., St George, A., \& Cullen, J. (2013). The Distinctive Features of Joint Participation in a Community of Learners. Teaching and Teacher Education, 31, 46-55.

Sheridan, S., \& Pramling Samuelsson, I. (2013). Preschool a Source for Young Children's Learning and Well-Being. International Journal of Early Years Education, 21 (2-3), 207-222.

Skidmore, D. (2007). Pedagogy and Dialogue. Cambridge Journal of Education, 36 (4), 503 514. doi.org/10.1080/03057640601048407

Smidt, S. (2009). Introducing Vygotsky: A Guide for Practitioners and Students in Early Years Education. Abingdon: Routledge.

Sommer, D., Pramling Samuelsson, I., \& Hundeide, K. (2010). Child Perspectives and Children's Perspectives in Theory and Practice. Milton Keynes: Springer.

Tatsis, K., Kafoussi, S., \& Skoumpourdi, C. (2008). Kindergarten Children Discussing the Fairness of Probabilistic Games: The Creation of a Primary Discursive Community. Early Childhood Education Journal, 36 (3), 221-26. doi.org/10.1007/s10643-008-0283-y

Vangsnes, V., \& Økland, N. T. G. (2013). Didactic Dissonance: Teacher Roles in Computer Gaming Situations in Kindergartens. Technology, Pedagogy and Education, 24 (2), 211 230.

Yelland, N. (2011). Reconceptualising Play and Learning in the Lives of Young Children. Australasian Journal of Early Childhood, 36 (2), 4-12.

Zurek, A., Torquati, J., \& Acar, I. (2013). Scaffolding as a Tool for Environment Education in Early Childhood. International Journal of Early Childhood Environmental Education, 2 (1), 27-57. 